\title{
Learning Engineering Knowledge and Creativity by Solving Projects
}

\author{
http://dx.doi.org/10.3991/ijep.v2i1.1873 \\ Chunfang Zhou \\ Aalborg University, Aalborg, Denmark
}

\begin{abstract}
Recent studies have argued the increasing complexity of engineering practice brings challenges to engineers. Creativity has been thought as one necessary element in engineering education. And to let students work with project work has been regarded as a good strategy of developing creativity. However, the literature shows studies on engineering education, most previous efforts take a departure of psychological perspective to discuss developing creative skills through project work; there is a lack of discussion on how project work supports achieving new knowledge and creativity in a social theory framework. Therefore, this paper aims to answer this lack and provide a literature review by focusing on three questions: 1) Which kinds of knowledge are needed for engineering students? 2) What are relationships between knowledge, learning and creativity? And 3) why does a solving project context support creativity and learning? Based on answering the three questions, the literature review underpins the needs of developing creativity in engineering education and strengths of solving project context in stimulating creativity and learning. So this paper contributes to future studies and practical strategies of fostering creative engineers.
\end{abstract}

Index Terms — creativity, engineering education, engineering knowledge, project work

\section{INTRODUCTION}

In essence, engineering is the process of integrating knowledge to some purpose. It is a societal activity focused on connecting pieces of knowledge and technology to synthesize new products, systems and services of high quality with respect for environmental fragility [1]. However, the globalization of engineering work has added urgency and complexity to reach the professional goals and values of future engineers [2]. Since engineering is situated within the realm of the human activities which consists of many heterogeneous highly interacting components, such as technology, economic, energy, environment, and ethics, etc [3]. As suggested by Sheppard et al. [2], because engineers' work directly affects the world, engineers must be able and willing to think about their ethical responsibility for the consequences of their interventions in an increasingly interlinked work environment. So engineering' status as a profession is complicated, and much of that complication is due to the staggering diversity of engineering disciplines and occupations [3].

Therefore, new profiles of engineers with abilities of responding to the challenges are required to be shaped by current education system. In Designing Engineers, Bucciarelli [4] makes the case that engineering is not an instrumental process: it is full of uncertainty and ambiguity. So engineers call on wide range knowledge, such as mathe- matical methods, marketing and finance [2]. Meanwhile, engineering students should master skills of creative thinking and learning, and creativity is one of the necessary abilities. As described in The Engineering of 2020 [5], engineers need "creativity" which is the ability to respond to challenges by combining "a broader range of interdisciplinary knowledge and a greater focus on systemic constructs and outcomes" in new ways. Creative engineers who are able to explore and scrutinize the available data or information and generate novel solutions to specific engineering problems or to the production of a unique product are demanded in work place [6].

Accordingly, some new strategies of teaching creativity have been explored in engineering education. To let students work with real-life projects has been thought as a good example. As argued by Blicblau and Stener [7], projects relate basic principles and concepts to real problems and help improve students' understanding, motivation and creativity. Projects reveal what young students can create and do when given the opportunity. Engineering students are strong on abstract conceptualization and active experimentation, and interested in practical uses for ideas and theories, likely to create and work hard and effectively if they see apparent use. In practice, this strategy has been integrated into engineering curriculum [7] and employed in diverse models, such as Project-Centered Learning [2] and Project-Based Learning [8].

However, most of previous studies take a departure of psychological perspective to view developing creativity by project work [6-7]. In the light of social theories of learning, this paper aims to provide a deeper understanding of the link between engineering knowledge, learning process, creativity and solving project context. This drives three main questions to be expected to answer:

1. Which kinds of knowledge are needed for engineering students?

2. What are the relationships between knowledge, learning and creativity?

3. Why does a solving project context support creativity and learning?

By answering these questions, a literature review will be provided by this paper. It will draw more attention to influences of educational environment on developing learning and creativity. Therefore, efforts in this paper will contribute to future educational strategies of fostering creative engineers.

\section{WHICH KINDS OF KNOWLEDGE ARE NEEDED FOR ENGINEERING STUDENTS?}

Professional practice depends on a specialized body of "engineering knowledge”. Engineers spend their time 


\section{SHORT PAPER}

\section{LEARNING ENGINEERING KNOWLEDGE AND CREATIVITY By SOLVING PROJECTS}

dealing mostly with practical problems, and engineering knowledge both serves and grows out of this occupation $[2,9]$. In terms of different kinds of engineering knowledge, there are mainly four descriptions in the literature, which can be thought as defining the knowledge body from the following views: (A) the general view, (B) the problem-solving view, $(\mathrm{C})$ the social contextual view, and (D) the knowledge existing view.

\section{A. A General View of Engineering Knowledge}

A general view of different kinds of knowledge has been discussed much in the literature [10-11]. According to the early work of Ryle [12], knowledge can be distinguished between "knowing that" and "knowing how". Ryle's work provides a useful framework to the following studies [13]. For example, Sheppard et al. [2] provide the descriptions of each kind of knowledge related to engineering practice:

- "Knowing that" means knowing the fundamental principles, theories and concepts of engineering;

- "Knowing how" means knowing how, when, where and why to use the theories and principles in analyzing engineering problems or situations.

In engineering practice, knowledge is a mixture of the two kinds, and is developed through engagement with the world. Since "knowing that" is one of the primary learning goals of engineering students; however, without "knowing how", students are not prepared for high-level analytic thinking, for this knowledge and this skill are essential to their cognitive development [2].

\section{B. The Problem-Solving View of Engineering Knowledge}

Problem-solving is one of the core activities of engineers [2]. As suggested by Sheppard et al. [14], three sections are involved in the model of engineering work: (1) engineering as problem solving, considering the systematic processes that engineers use to define and resolve problem; (2) engineering as knowledge, considering the specialized knowledge that enables, or it you will, fuels the process; and (3) engineering as the integration of process and knowledge. Accordingly, a summary of three kinds of engineering knowledge is provided:

- Knowledge that van be 'put into play' (knowing how, that, why and when)

- Knowledge that is continually changing (expanding, evolving)

- Knowledge that ranges from science-based to contextual, from tacit to procedural

Sheppard et al. [14] also point out engineering practice is the complex, thoughtful and intentional integration process of problem-solving and specialize knowledge towards some meaningful end. And the integration of process and knowledge happens within the mind of a single engineer and between engineers. Very little engineering work is solitary, and it is increasingly being recognized as a social process [4].

\section{The Social Contextual View of Engineering Knowledge}

More specially, there is an increasing need for engineers to choose technological solutions that are appropri- ate to their social context and to give consideration to the long-term impacts of their work, if only because the work of engineers can have wide-ranging effects [15]. From this sense, Sheppard et al. [2] lists a body of engineering knowledge based on previous work of Vincenti [9], Koen [16] and Kroes [17]. As the Table 1 suggests, engineers call on wide ranging knowledge, from theoretical tools to contextual knowledge.

TABLE I.

KNOWLEDGE TYPES USED BY ENGINEERS

\begin{tabular}{|c|c|}
\hline Knowledge type & Description \\
\hline $\begin{array}{l}\text { Theoretical tools: } \\
\text { Math-based, and } \\
\text { conceptual }\end{array}$ & $\begin{array}{l}\text { Mathematical methods and structured knowl- } \\
\text { edge, scientific, engineering and phenomenol- } \\
\text { ogical theories, intellectual concepts. 'Engineer- } \\
\text { ing science' consists of specific combinations of } \\
\text { math and science around particular engineering } \\
\text { domains. }\end{array}$ \\
\hline $\begin{array}{l}\text { Fundamental design } \\
\text { concepts: Opera- } \\
\text { tional principles and } \\
\text { normal }\end{array}$ & $\begin{array}{l}\text { Operational principle describes 'how [a de- } \\
\text { vice's/ technology's] characteristic parts fulfill } \\
\text { their special function in combination to an over- } \\
\text { all operation which achieves the purpose'- in } \\
\text { essence, how the device (technology) works. } \\
\text { Normal configurations describe what is typi- } \\
\text { cally taken for the shape and arrangements for a } \\
\text { particular class of devices (technologies). }\end{array}$ \\
\hline $\begin{array}{l}\text { Criteria and specifi- } \\
\text { cations }\end{array}$ & $\begin{array}{l}\text { Technical criteria appropriate to a class of de- } \\
\text { vices (technologies), including numerical per- } \\
\text { formance criteria. (e.g., impact performance } \\
\text { criteria in the automotive sector, pressure vessel } \\
\text { standards in the chemical industry) }\end{array}$ \\
\hline Quantitative data & $\begin{array}{l}\text { Physical properties and quantities required in } \\
\text { formulas and required to demonstrate device } \\
\text { performance. Understanding of procedures and } \\
\text { processes for generating such properties and } \\
\text { quantities. }\end{array}$ \\
\hline $\begin{array}{l}\text { Practical considera- } \\
\text { tions }\end{array}$ & $\begin{array}{l}\text { Tacit knowledge (typically learned on the job) } \\
\text { generally not codified. In addition, rules of } \\
\text { thumb and heuristics (this category was called } \\
\text { 'Design Considerations' by Vincenti [9]). } \\
\end{array}$ \\
\hline $\begin{array}{l}\text { Process-facilitating } \\
\text { strategies }\end{array}$ & $\begin{array}{l}\text { Knowledge of tools and strategies for project } \\
\text { management, leadership, teamwork, communi- } \\
\text { cations and management. }\end{array}$ \\
\hline $\begin{array}{l}\text { Contextual knowl- } \\
\text { edge }\end{array}$ & $\begin{array}{l}\text { Knowledge of values (personal, professional, } \\
\text { cultural). } \\
\text { Knowledge of norms (what is acceptable behav- } \\
\text { ior, what is expected behavior). } \\
\text { Knowledge of contexts and contextual factors } \\
\text { that constitute the artifact's aesthetic. }\end{array}$ \\
\hline
\end{tabular}

Although Sheppard et al. [14] also argue that table1 is probably problematic to represent a single engineer's body of knowledge - not all knowledge types will be needed for every engineering project and not all practicing engineers need be expert in every knowledge type to be successful, the knowledge types shown in table 1 demonstrate the new educational approach is needed. As argued by Beder [15], a broader, more general approach is required that not only helps students to understand basic engineering principles but also gives them the ability to acquire more specialized knowledge. And beyond this, there is also a need to provide young engineers with a social context within which they will work, together with skills in critical analysis and ethical judgement and an ability to assess the longterm consequences of their work. 


\section{The Knowledge Existing View of Engineering Knowledge}

In terms of the knowledge existing models in relevant context of companies, corporations or groups, the explicit knowledge and the tacit knowledge have been discussed much [18-19]. The two models also make sense in engineering knowledge if we take considerations of economic and commercial value of engineering [3]. Smith [19] lists the use of tacit and explicit knowledge in workplace:

- Tacit knowledge: practical, action-oriented knowledge or "know-how" based on practice, acquired by personal experience, seldom expressed openly, often resembles intuition.

- Explicit knowledge: academic knowledge or "knowwhat" that is described in formal language, print or electronic media, often based on established work processes, use people-to-documents approach.

Furthermore, in organizational context, two levels of knowledge are often mentioned in literature [18]:

- Individual knowledge

- Collective knowledge

Both levels include the tacit and the explicit knowledge. As mentioned previously, the engineering work is increasingly a highly collaborative process. The scope, timeframes, and complexity of most projects require the efforts of teams of engineers - experts in some aspects of engineering practice working in coordination with other experts [2]. The collective intelligence, then, has been recognized as a new weapon, which presupposes communication, coordination, cooperation, conversation..., co-, that is, links, exchanges, messages. So the level of collective knowledge certainly increases, but that of individual knowledge and expertise diminishes, at least relatively [18].

The literature review in this section demonstrates diverse views of engineering knowledge, although overlapping exist between some views, for example, both the general view and the knowledge existing view include "knowing how". However, the different views demonstrate engineering students are required to master a complex body of knowledge. Furthermore, to successfully integrate process and knowledge, engineers must not only stay informed about new and emerging technologies but also be aware of knowledge and skills from other domains [2].Therefore, engineers need a creative mind to meet the advancing goal of the engineering profession - to design new products or systems and improve existing ones for the benefit of humankind [20].

\section{WHAT ARE THE RELATIONSHIPS BETWEEN KNOWLEDGE, LEARNING AND CREATIVITY?}

Creativity is generally considered to involve the generation of novel but useful ideas, which has gained widespread acceptance $[6,13]$. A social approach to creativity emphasizes more the shaping roles of social context than individual personality on developing creative ideas [13].

The role of creativity is increasingly acknowledged within engineering education research [21]. On the discussions of creativity and learning, many studies focus on how to train engineering students to develop creative thinking skills from psychological perspective [6]. However, in the light of social theory and research on knowl- edge management, creativity and learning can be linked by conversations between different kinds of knowledge [18]. Accordingly, the following section is organized as: (A) learning as knowledge conversations, and (B) creativity as a driver to knowledge conversions.

\section{A. Learning as Knowledge Conversations}

The social theories approaches bring some new insights to leaning research [22]. Researchers from these approaches call on that knowledge is achieved more from construction than memorizing, so learning is developed more by interaction between person and environment and collaborative process than individual cognitive process $[13,22]$. A series of studies on knowledge conversions in organizational context also underpin the points within the framework of social theories. One of classic model is developed by Nonaka and Takeuchi [18], as shown in Figure 1.

Nonaka and Takeuchi’ work has been broadly accepted and developed, especially in methods of knowledge management [18]. In the following work, Nonaka and Konno [23] introduce the concept of $\mathrm{Ba}$, the space in which knowledge resides; this space assumes various forms according to the types of knowledge and their conversion. It should be understood that knowledge depends on its context. As mentioned by Corsi et al. [18], we know only in the moment in which we need to know: knowledge is quintessentially contextual and is triggered by circumstances. So models of knowledge conversation have taken the social practice into account. For example, Baumard's model demonstrates conversations among four types of knowledge [24], as shown in Figure 2.

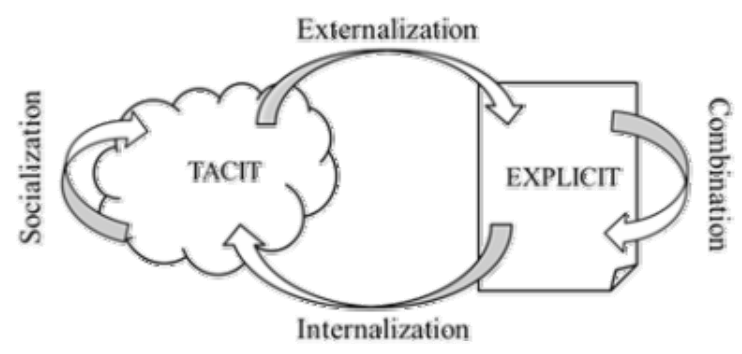

Figure 1. Model of Knowledge Conversion according to Nonaka and Takeuchi

Notes of Figure 1:

Socialization: The sharing of tacit knowledge requires a direct interaction between individuals, but also in the direct exchanges between pairs. The key to socialization is experience.

Externaliza- The explanation of tacit knowledge (writing a tion: report or a manual, modelization, conceptualization) entails setting aside, at least partially, the context of the initial tacit knowledge; the knowledge produced becomes much easier to duplicate to diffuse.

Combination: This is the conversion of the existing explicit knowledge into new explicit knowledge by addition, restricting, diffusion and confrontation.

Internaliza- The "incorporation” of explicit knowledge, done tion: individually or collectively through training programs or exercises which allow the integration of shared knowledge, in the form not only of formal documents but also spoken accounts, and return of experience. 


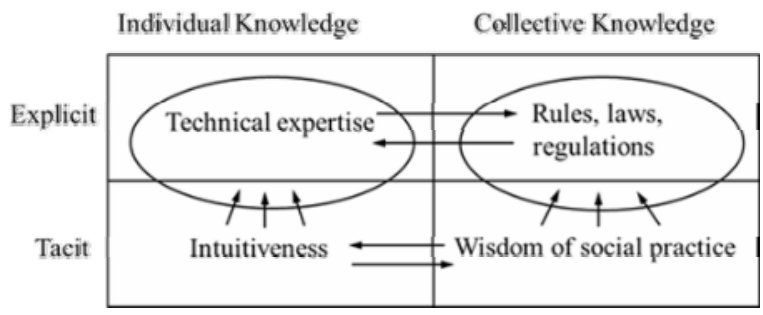

Figure 2. Model of Knowledge Conversion according to Baumard

Notes of Figure 2:

Firstly, knowledge is explicit and individual, techniques that allow us to counter nets and traps.

Secondly, we achieve collective knowledge and profound knowledge of a terrain, environment, rules and laws.

Thirdly, knowledge is tacit and collective, which is of the unspoken, of the invisible structure of a practice.

Lastly, knowledge is tacit and individual. Tacit expertise is complemented by "hard" technical knowledge - a sort of inimitable technical skills.

These four forms of knowledge are indissociable.

From the two models reviewed above, it is clear that the fundamental hypothesis of previous work related to conversations of knowledge is that there are four basic kinds of knowledge - tacit knowledge, explicit knowledge, individual knowledge and collective knowledge. The learning process is not linear, however, is in a "back" and "forth" exchange between different kinds of knowledge. The tacit and explicit forms of knowledge interact with each other uninterruptedly within a dynamic process [18].

\section{B. Creativity as a Driver to Knowledge Conversations}

For engineering students, creativity is an inspirational force that generates new ideas or produces novel combinations of existing ideas, leading to further solutions or deeper understanding [25]. Moreover, any new idea could be potential to start learning new knowledge. As Craft [13] emphasizes, we can see creativity as, effectively, offering students opportunities to shape new knowledge. And shaping new knowledge cannot occur without some understanding of what already exists, and without opportunities to engage with this and take it to a new palace. In other words, knowledge conversations always happen when students are creating knowledge. Therefore, creativity can be understood as a driver to knowledge conversations in learning process.

Especially in a collaborative context, participants build on each other's ideas in order to reach an understanding that was not available to any of the participants initially and group members must also enter into critical and constructive negotiations of each other's suggestions. Meanwhile, well-grounded arguments and counter-arguments need to be shared and critically evaluated through collective talk. These conditions are similar to those needed for collaboration in creative endeavors. For such considerations, educational professions are increasingly coming to realize that learning and creativity go hand in hand [26].

\section{Why Does A SOVLing Project CONTEXT Support CREATIVITY AND LEARNING?}

It is believed that a good way to teach technology is to provide students with real technological problems [27]. Since the project relates basic principles and concepts to real problems, working with the real-life project has been welcomed by future engineers. According to AlgreenUssing [28] (quoted and translated by Graaff and Kolmos [29]), the "project" may be defined as follows:

A project is a complex effort that necessitates an analysis of the target (problem analysis) and that must be planned and managed, because of desired changes that are to be carried out in people's surroundings, organization, knowledge, and attitude to life; it involves a new, not previously solved task or problem; it requires resources across traditional organizations and knowledge; it must be completed at a point in time determined in advance.

Based on this definition of project, the focus in this section is on roles of project in developing learning and creativity for engineering students. Adopting this focus within the existing literature leads to propose four major dimensions [30]: (A) problem analysis and solving, (B) group learning, (C) interdisciplinary learning, and (D) project management.

\section{A. Problem Analysis and Solving}

The ability to solve and analyze problems is an essential attribute for an engineer, and one that should be developed, by whatever means, to the full potential in engineering undergraduates. Adams and Turner [31] proposed a number of interdependent and interactive capacities when we solve problems. Creativity is included and motivation is a driving capacity. This process involves the identification of the problem and problem constraints; identification and clarification of multiple, and possibly conflicting, perspectives of the problem; generation of possible solutions; assessment of the viability of alternative solutions through argument construction and articulation of personal beliefs and assumptions; monitoring of the metacognitive processes involved with the problem-solving activity; testing and recommendation of a solution; and adaptation of a solution [32-33]. Thus in a problem solving for real-life context, the learning process is creative, dynamic and iterative.

\section{B. Group Learning}

Previous studies support the use of learning groups in problem-solving contexts, because groups can provide a means for students to share and examine others' interpretations and perspectives as they work through the problem [33]. Meanwhile, task-related diversity is needed in groups for different ideas to generate [34]. The literature shows there is increasingly evidence that group learning can be a valuable tool for promoting creativity. It can foster higher-order thinking skills such as analytical reasoning, synthesis of multiple information that stream into a whole that is indeed greater than the sum of its parts, and evaluation [35]. It can also develop team spirit which encourages the group members to care about the group, because they want it to succeed. Furthermore, group learning can facilitate not only the acquisition of knowledge but also several other desirable attributes such as communication skills, teamwork, problem solving, independent responsibility for learning, sharing information and respect for others [36-37].

\section{Interdiciplinary Learning}

Interdisciplinary learning involves crossing professional discipline borders [29]. According to studies on communities of practice [22], the interdisciplinary projects require the contribution of multiple disciplines. Participating in 


\section{SHORT PAPER}

\section{LEARNING ENGINEERING KNOWLEDGE AND CREATIVITY By SOLVING PROJECTS}

these kinds of projects exposes practitioners to others in the context of specific tasks that go beyond the purview of any view of any practice. People confront problems that are outside the realm of their competence but that force them to negotiate their own competences with the competences of others. Moreover, competence and experience are in different relationships at the core and at the boundaries of practices, at the encounters between generations, and in relationships of power among participants. The innovation potential of a system lies in its combination of strong practices and active boundary processes - people who can engage across boundaries, but have enough depth in their own practice that they can recognize when something is really significantly new. Accordingly, simultaneous participation in communities of practice and project teams creates leaning loops that combine application with capability development [38].

\section{Project Management}

In order to ensure task accomplishment and stimulate group dynamic, project management is essential to support learning activities. Amabile [39] suggested good project management is one of the qualities in work environments that served to promote creativity from a socialpsychology approach. Meanwhile, the other related qualities has been proposed such as freedom in deciding what to do or how to accomplish the task , the sense of control over one's own work and ideas, management enthusiasm for new ideas and their ability to create an atmosphere free of threatening evaluation, sufficient resources and time, pressure and so on. The ability of a manager will be tested to the utmost when complex technical changes demand a high level of corporate activity. A premium is placed upon fixing clear objectives, setting up high-response decisionmaking, communication and control systems to enable a wide range of resources and disparate talents to be harnessed to the full [27].

To summarize, the literature review in this section reveals the supporting roles of project work in developing learning and creativity from four dimensions: problem solving and analysis, group learning, interdisciplinary learning and project management. However, any kind of social context could be one system that means the four dimensions are not isolated but are mutually influential in stimulating a creative learning environment. Meanwhile, it should be noted here that teacher's pedagogic strategies and attitudes can also have an impact on creativity - it is the key to ensure the strengths of project work in developing creativity. Some studies show teachers who see themselves as the ultimate authority, and expect obedience and respect rather than challenges from students, won't be able to inspire students' creative thinking well. On the other hand, if teachers work from the assumption that their role is to help every student reach their inner potential, they will encourage and reward creative behavior in learning [40]. From this sense, Problem and Project-Based Learning (PBL) has been suggested as a creative learning environment and employed around the world due to its core philosophy of "student-centered learning” [29, 41-42].

\section{CONCLUSION}

The social approaches to learning have brought new insights to engineering education research. However, there are not many discussions focusing on how learning environment influences creativity from these approaches.
Based on literature review, this paper illustrates a link between engineering knowledge, learning process, creativity and solving project context. As the literature demonstrates, engineering students are required to master a complex body of knowledge in order to face future work challenges. However, creativity is the necessary ability because it could be one of the drivers in learning process by stimulating knowledge conversions. In other words, creativity helps engineering students to find as many as opportunities of exploring new knowledge. While solving project context offers a suitable learning environment of developing creativity through dimensions of problem solving, group learning, interdisciplinary learning and project management. Meanwhile, the "student-centered learning" is suggested to the teachers who are employing the strategy of solving projects. For only when students feel free and excited to express their new ideas and risky behavior, creativity could be increased in learning process. Accordingly, more efforts should be done on developing creativity in engineering education from both learning and teaching perspectives within social theories framework in the future.

\section{REFERENCES}

[1] J. Bordogna, "Engineering - the integrative profession", NSF Directions, Vol.20, No. 2, pp.1, 1992.

[2] F. S. D. Sheppard, K. Macatangay, A. C. William and M. Sullivan, Educating Engineers, Designing for the Future. San Franciso: Jossey-Bass, 2009.

[3] H. Christensen, B. Delahousse and M. Meganck, Engineering in Context. Denmark: Authors and Academica, 2009.

[4] L. L. Bucciarelli. Designing Engineers. Cambridge, Massachusetts: The MIT Press, 1996.

[5] National Academy of Engineering, The Engineer of 2020: Vision of Engineering in the New Century. Washington, DC, USA: National Academies Press, 2004.

[6] Z. Liu and D. J. Schönwetter, "Teaching creativity in engineering”. International Journal of Engineering Education, Vol. 20, No. 5, pp. 801-808, 2004.

[7] A. S. Blicblau and J. M. Steiner, "Fostering creativity through engineering projects”, European Journal of Engineering Educaiton, Vol. 23, No. 1, pp. 55-65, 1998. http://dx.doi.org/10.1080/ $\underline{0304379980230107}$

[8] J. E. Mills and D. F. Treagust, "Engineering education — is Problem Based Learning or Project-Based Learning the answer?” Australasian Journal of Engineering Education, Online Publication, Vol. 4, 2003.

[9] W. Vincenti, What Engineers Know and How They Know It: Analytical Studies from Aeronautical History. Baltimore, MD: The Johns Hopkins University Press, 1990.

[10] R. Garud, "On the distiction between know-how, know-why and know-what”, In H. J. Walsh (eds.) Advances in Strategic Management, Grennwich, CT: JAI press, 1997.

[11] wJ. S. Brown and P. Duguid, "Knowledge and organization: a social-practice perspective”, Organization Science, Vol.12, No. 2, pp.198-213, 2001.

[12] G. Ryle, The Concept of Mind. London: Hutchinson, 1949.

[13] A. Craft, Creativity in Schools, Tensions and Dilemmas. London: Routledge, 2005. http://dx.doi.org/10.4324/9780203357965

[14] S. Sheppard, A. Colby, K. Macatangay, and W. Sullivan, "What is engineering practice?” International Journal of Engineering Education, Vol.22, No.3, pp. 429-438, 2006.

[15] B. S. Beder, "Beyond technicalities: expanding engineering thinking”, Journal of Professional Issues in Engineering Education and Practice, Vol. 125, No. 1, pp. 12-18, 1999. http://dx.doi.org/ 10.1061/(ASCE)1052-3928(1999)125:1(12)

[16] B. V. Koen, Discussion of The Method: Conducting The Engineering Approach to Problem Solving, NY: Oxford University Press, 2003. 


\section{SHORT PAPER}

\section{LEARNING ENGINEERING KNOWLEDGE AND CREATIVITy By SOLVING PROJECTS}

[17] P. Kroes, "Technical and contextual constraints in design; an essay on determinants of technological design”, Social Sciences: The Role of Design in the Shaping of Technology, Volume 5, Proceedings from the COST A3 and Cost A4 Workshop, pp. 43-76, France: Lyon, 1995.

[18] P. Corsi, S. Richir, H. Chiristofol and H. Samier, Innovation Engineering: The Power of Intangible Networks. London: ISTE Ltd, 2006.

[19] E. A. Smith, "The role of tacit and explicit knowledge in the workplace”, Journal of Knowledge Management, Vol.5, No.4, pp.311-321, 2001. http://dx.doi.org/10.1108/13673270110411733

[20] J.C. Martin, “Compete professionalism for engineers”, Frontiers in Education Conference, IEEE, Washington, DC, 1991.

[21] C. Charyton and J. A. Merrill, "Assessing general creativity and creative engineering design in first year engineering students", Journal of Engineering Education, Vol. 98, No. 2, pp.145-156, 2009.

[22] E. Wenger. Communities of Practice, Learning, Meaning and Identity. New York: Cambridge University Press,1998.

[23] I. Nonaka and H. Konno, “The concept of Ba”. California Management Review, Vol. 40, No. 3, pp.40-54, 1998.

[24] P. Baumard. Tacit Knowledge in Organizations. London: SAGE Publications, 1999.

[25] G. Pahl, W. Beitz, J. Feldhusen and Grote, K. H. Engineering Design: A Systematic Approach (The 3rd edition). London: Springer, 2007.

[26] A. Eteläpelto and J. Lahti, “The resources and obstacles of creative collaboration in a long-term learning community”. Thinking Skills and Creativity, Vol. 3, pp. 226-240, 2008. http://dx.doi.org/ 10.1016/j.tsc.2008.09.003

[27] S. A. Gregory, B. Sc.Eng and F. I. E. Chem, Creativity and Innovation in Engineering. London: Butterworths, 1972.

[28] H.Algreen-Ussing and N.O. Fruensgaard, Melode I Projektarbejde. Aalborg: Aalborg University Press, 1990.

[29] Graaff, de E. and A. Kolmos, Management of Change, Implementation of Problem-Based and Project-Based Learning in Engineering. Rotterdam: Sense Publishers, 2007.

[30] C. Zhou, A. Kolmos, X. Du and J. F. D. Nielsen, “Group creativity development by solving real-life project in engineering education", Excellence in Education 2009-2010: Leading minds creating the future: Proceedings of the Annual Conference of the International Centre for Innovation in Education (ICIE) held in Ulm-Germany (August 24-27, 2009); and Athens-Greece (June 812, 2010) , ICIE: International Centre for Innovation in Education, Ulm-Germany, 2011.

[31] J. P. Adams and S. Turner. "Problem solving and creativity for undergraduate engineers: process or product?” Innovation, Good Practice and Research in Engineering Education, P061, 2008.
[32] R. J. Defillippi, "Introduction: Project-based Learning, reflective practices and learning outcomes”. Management Learning, Vol.32, pp.5-10, 2001. http://dx.doi.org/10.1177/1350507601321001

[33] M. C. Lohman and M. Finkelstein, "Designing groups in problembased learning to promote problem-solving skill and selfdirectedness”. Instructional Science, Vol.28, pp.291-307, 2000. http://dx.doi.org/10.1023/A:1003927228005

[34] B. A. Nijstad and W. Stroebe, "Four principles of group creativity. In L. L. Thompson and H. S. Choi (eds.), Creativity and Innovation in Organizational Team, pp.161-177. London: Lawrence Erlbaum Associates, Publishers, 2006.

[35] G. F. Smith, "Problem-based learning: can it improve managerial thinking?” Journal of Management Education, Vol. 29, pp.357376, 2005. http://dx.doi.org/10.1177/1052562904269642

[36] H. Awang and I. Ramly, "Creative thinking skill approach through problem-based learning: pedagogy and practice in the engineering classroom”. International Journal of Social Sciences, Vol.3, pp.18-23, 2008.

[37] D. Livingstone and K. Lynch, "Group project work and studentcentered active learning: two different experiences”. Studies in Higher Education, Vol.25, No.3, pp.325-345, 2000. http://dx.doi.org/10.1080/713696161

[38] E. Wenger, Learning for a Small Planet: A Research Agenda. Scientific Project Description. Retrieved April 6, 2009 from http://ewenger.com/research/LSPfoundingdoc.doc.

[39] T. M. Amabile, Creativity in Context, Update to the Social Psychology of Creativity. United States: Westview Press, 1996.

[40] A. K. Ng, "A cultural model of creative and conforming behavior.” Creativity Research Journal, Vol. 15, No. 2-3, pp. 223-233, 2003. http://dx.doi.org/10.1080/10400419.2003.9651414

[41] D. Dolmans, "Solving problems with group work in problembased Learning: hold on to the philosophy", Medical Education, Vol. 35, pp. 884 - 889, 2001. http://dx.doi.org/10.1046/j.13652923.2001.00915.x

[42] O.S. Tan, Problem Based Learning and Creativity. Singapore: Cengage Learning Asia Pte Ltd, 2009.

\section{AUTHORS}

Chunfang Zhou is with the UNESCO Chair in Problem Based Learning, Department of Development and Planning, Aalborg University, Denmark. Fibigerstraede 13, DK-9220, Aalborg, Denmark (e-mail: chunfang@ plan.aau.dk).

Received 14 November 2011. Published as resubmitted by the author 17 January 2012 